\title{
Effect of Sucrose Solution and Chemical Preservatives on Overall Quality of Strawberry Fruit
}

Arsalan Khan ${ }^{1 *}$, Baber Shamrez ${ }^{1}$, Uzma Litaf', Alam Zeb², Ziaur Rehman², Rozina Naz ${ }^{2}$, Sher Hassan Khan ${ }^{3}$ and Abdul Sattar Shah ${ }^{3}$

${ }^{1}$ Department of Food Science and Technology, Agriculture Research Institute, Tarnab, Peshawar, Pakistan

${ }^{2}$ Department of Food Science and Technology, The University of Agriculture, Peshawar, Pakistan

${ }^{3}$ Department of Food Science and Technology, The University of Swabi, Khyber PakhtunKhwa, Pakistan

\begin{abstract}
This research work was conducted to study the effect of sucrose solution with different chemical preservatives on overall quality of the strawberry fruit kept at ambient temperature. The treatments were : S0 (Control), S1 (Strawberry fruit + sucrose solution (30o brix) + Sodium benzoate $0.1 \%$ ), S2 (Strawberry fruit + sucrose solution (30o brix) + Potassium sorbate $0.1 \%$ ), S3 (Strawberry fruit + sucrose solution (40o brix) + Sodium benzoate $0.1 \%)$, S4 (Strawberry fruit + sucrose solution (40o brix) + Potassium sorbate $0.1 \%$ ), S5 (Strawberry fruit + sucrose solution (30o brix) + Sodium benzoate 0.05\% + Potassium sorbate $0.05 \%$ ), S6 (Strawberry fruit + sucrose solution (40o brix) + Sodium benzoate $0.05 \%+$ Potassium sorbate $0.05 \%$ ). All these treatments were examined physicochemically (Titratable acidity, $\mathrm{pH}$, ascorbic acid, TSS, reducing and non-reducing sugar) and organoleptically (Texture, flavor, color and overall acceptability) at each 15 days interval for three months. Storage results shown that Decreased was found in $\mathrm{pH}$ from (3.49 to 3.32), ascorbic acid from (54.82 to $30.08 \mathrm{mg} / 100 \mathrm{~g}$ ), non-reducing sugar from (20.41 to $13.36 \%$ ), color score from (9 to 4.96), texture score from (9 to 5.14), flavor score from (9 to 5.23) and overall acceptability score from (9 to 5.40 ) while increased were found in TSS from (17.17 to 21.01 oBrix), titratable acidity from $(0.38$ to $0.53 \%)$ and reducing sugar from ( 8.35 to $11.16 \%$ ) throughout storage period. The highest mean value for $\mathrm{pH}$ was occurred in treatment S1 (3.45), titratable acidity in S3 $(0.50 \%)$, TSS in S6 (24.76oBrix), ascorbic acid in S5 $(46.30 \mathrm{mg} / 100 \mathrm{~g})$, reducing sugar in S6 (11.69\%), non-reducing sugar in S1 (19.65\%), color in S5 (7.60), texture in S1 and S5 (7.46), flavor in S3 and S5 (7.60) and overall acceptability in S2 (7.83). Statistical results revealed that treatment $S 5$ followed by $S 1$ were found adequate both physicochemically and organoleptically.
\end{abstract}

Keywords: Strawberry; Sorbate; Benzoate; Sucrose; Ambient temperature

\section{Introduction}

Strawberry (Fragaria Spp.) belongs to kingdom Plantae and herbaceous member of family "Rosaceae". Over six hundred varieties occurred which differ in taste, texture and size [1]. Strawberry is one of the important fruit among the berries. Various strawberry species grow wild all over the world, but the cultivated strawberry is based upon two species Fragarin Chiloensis and Fragarin Verginiana. Hybrids between these two species were the precursor of all the present strawberry cultivars [2]. Strawberry crop is recently introduced in Pakistan; its production in Pakistan is very low as compared to other countries of the world where strawberries were grown. In Pakistan it is grown inside definite places of Punjab, Islamabad and Khyber Pakhtunkhwa [3]. There are many varieties grown in the world but the main promising varieties grown in Pakistan are Mission, Corona, Tuft, Sweet Charlie, Super faction and Festival. During 2009-10 strawberry was grown on an area of about 193 acres and its production was 274 tons in Pakistan [4]. According to Food and Agriculture Organization (FAO), world production of strawberries has exceeds 4 million tons, in which United States contributes 28 percent [5]. Nutritionally, One cup of strawberry contains $1 \mathrm{~g}$ protein, $10.5 \mathrm{~g}$ carbohydrates, $0.6 \mathrm{gm}$ fat, $1.6 \mathrm{gm}$ fiber, 0.1 $\mathrm{mg}$ thiamin, $84.5 \mathrm{mg}$ vitamin $\mathrm{C}, 26.4 \mathrm{mg}$ folic acid, $0.1 \mathrm{mg}$ riboflavin, $0.4 \mathrm{mg}$ niacin, $0.2 \mathrm{mg}$ zinc, $0.6 \mathrm{~g}$ iron, $2 \mathrm{~g}$ sodium, $21 \mathrm{~g}$ calcium, 16 $\mathrm{mg}$ magnesium, $45 \mathrm{kcal}$ calories. Vitamin $\mathrm{C}$ level of Strawberry fruit is more than oranges. Strawberry fruit also give an exceptional supply of vitamin $\mathrm{K}$, vitamin $\mathrm{B} 5$, vitamin B6, manganese, magnesium, copper, potassium and omega 3 fatty acids (USDA, 2008) [6,7]. Malic and Citric acids are main organic acids which contribute to aroma. Strawberries also contain the higher percentage of non-nutrients e.g. phenols and flavonoids as compared to other berry fruit [8]. Strawberry fruit have juicy, tiny, flavorful, nourishing, syrupy flavor, diuretic, remineralizing, tonic and astringent attributes [9]. The strawberry fruit can be used both in fresh form and preserved to Jellies, James and squashes that can be consumed in off season [10]. Osmotic Dehydration (OD) is a technology that partially removes the water from fruits and vegetables, when it is dipped in a hypertonic solution of salt, sugar or others. This process is successfully applied to those fruit and vegetable, which is perishable and cannot be supplied to market in fresh form. However, $\mathrm{OD}$ is a pretreatment course of action so further is process is necessary for the stability of the product. Osmotic Dehydration Method (OD), also named dewatering and impregnation by immersion in concentrates or by immersion of fruits and vegetable in concentrated solutions or syrups of soluble solids, without phase change [11]. Sugar provides sweet taste and flavor to the product; they also provide freshens and contributes to the product quality [12]. Different chemical preservatives are used in food products to extend their shelf life but the most important are sodium benzoate, potassium sorbate, potassium metabisulphite, sorbic acid, sulphur dioxide etc. Potassium sorbate, retard yeasts and molds growth in numerous food stuffs like yogurt, cheese, wine, dried meats and dehydrated commodities. Sodium benzoate is a becteriostatic and fungistatic preservative underneath acidic environment and is mostly used in acidic foods like salad dressings (vinegar), carbonated munchies (carbonic acid) and condiments [13]. Nonetheless, the future of strawberry production and processing might be very much bright in

*Corresonding author: Arsalan Khan, Department of Food Science and Technology, Agriculture Research Institute, Tarnab, Peshawar, Pakistan, Tel: +923149602556; E-mail: arsalankhan.fst@gamil.com

Received September 01, 2014; Accepted December 06, 2014; Published January 07, 2015

Citation: Khan A, Shamrez B, Litaf U, Zeb A, Rehman Z, et al. (2014) Effect of Sucrose Solution and Chemical Preservatives on Overall Quality of Strawberry Fruit. J Food Process Technol 6: 413 doi:10.4172/2157-7110.1000413

Copyright: (c) 2014 Khan A, et al. This is an open-access article distributed unde the terms of the Creative Commons Attribution License, which permits unrestricted use, distribution, and reproduction in any medium, provided the original author and source are credited. 
our country in general and Khyber Pakhtunkhwa in particular because this fruit fetches maximum economic returns for the farmer. Due to the perishability of strawberry fruit, this research work was designed to prepare a value added product from strawberry i.e osmic-dehydrated product which will be available throughout the year in a market. The farmers will be benefitted while getting proper return for their produce.

\section{Materials and Methods}

Sound, healthy and ripened strawberries were purchased from the orchard at Charsadda and were brought to the laboratory of Food Technology section, Agriculture Research Institute, Tarnab Peshawar where research work was conducted. Strawberry fruit with decent texture and color were selected. After washing with cold water the stalks of the fruits were removed with stainless steel knives. Two different concentrations of sucrose solutions $\left(30^{\circ} \mathrm{Brix}\right.$ and $\left.40^{\circ} \mathrm{Brix}\right)$ were prepared with supplementation of different chemical preservatives (Sodium benzoate and Potassium sorbate). The treatment were numbered as, $S_{0}$ (Control), $S_{1}$ (Strawberry fruit + sucrose solution $\left(30^{\circ}\right.$ brix $)+$ Sodium benzoate $0.1 \%), S_{2}$ (Strawberry fruit + sucrose solution $\left(30^{\circ}\right.$ brix $)+$ Potassium sorbate $0.1 \%), S_{3}$ (Strawberry fruit + sucrose solution $\left(40^{\circ}\right.$ brix) + Sodium benzoate $0.1 \%), \mathrm{S}_{4}$ (Strawberry fruit + sucrose solution $\left(40^{\circ}\right.$ brix $)+$ Potassium sorbate $\left.0.1 \%\right), \mathrm{S}_{5}$ (Strawberry fruit + sucrose solution $\left(30^{\circ}\right.$ brix $)+$ Sodium benzoate $0.05 \%$ + Potassium sorbate $0.05 \%), S_{6}$ (Strawberry fruit + sucrose solution $\left(40^{\circ}\right.$ brix $)+$ Sodium benzoate $0.05 \%$ + Potassium sorbate $0.05 \%$ ). The whole strawberry fruit were immersed in $500 \mathrm{ml}$ sterilized plastic jars filled up with sucrose solution. For analysis and shelf life study, the jars were completely sealed and stored at ambient temperature.

\section{Chemical analysis}

Acidity, $\mathrm{pH}$, Total soluble solids, reducing and non reducing sugar, Ascorbic acid were evaluated through standard methods of AOAC (2012) [14].

\section{Organoleptic analysis}

Organoleptic analysis (flavor, color, texture and overall acceptability) was done by using Larmond scale [15] at an interval of 15 day for a total period of three months at room temperature.

\section{Statistical analysis}

All the data concerning treatments and storage interval were statistically analyzed by means of completely Randomized Design (CRD) 2 Factorial and the means were separated by applying Least Significant Difference (LSD) Test at $5 \%$ possibility level as defined by Steel and Torrie [16].

\section{Results and Discussion}

\section{Chemical analysis}

$\mathbf{p H}$ : $\mathrm{pH}$ of the fruit is mainly associated to the flavor and perishability. The mean $\mathrm{pH}$ values decrease during storage from 3.49 to 3.32 (Table 1). The highest percent decreased was found in $\mathrm{S}_{6}(5.71 \%)$ followed by S2 (5.20\%) while the lowest percent decrease was observed in $\mathrm{S}_{1}(3.99 \%)$ followed by $\mathrm{S}_{5}(4.02 \%)$. The results are in agreement with the conclusions of Fasogbon et al. [17] who observed decrease in $\mathrm{pH}$ value during osmotic dehydration and rehydration characteristics of pineapple slices. A similar result in decreased of $\mathrm{pH}$ value in strawberry syrup was also reported by Khan [18] due to the development of acidic compounds.
Total soluble solid (TSS): The mean Total Soluble Solids of the treatments increase from 17.17 to $21.01^{\circ}$ brix during storage. Highest percent increase was found in $\mathrm{S}_{0}(83.05)$ followed by $\mathrm{S}_{3}(25.32)$ while lowest percent increase was observed in $S_{2}(16.0)$ followed by $S_{6}(21.25)$ as shown in Table 2 . Similarly Kumar and Devi observed an increase in total soluble solid during osmo dehydration of pineapple slices.

Titratable acidity (\%): Mean values for Titratable acidity increase from 0.38 to 0.53 during storage period (Table 3 ). The highest percent increase was observed in $\mathrm{S}_{0}(31.63 \%)$, followed by $\mathrm{S}_{3}(30.51 \%)$ while lowest percent increase was noted in $S_{1}(25.0 \%)$, followed by $S_{5}(27.27$ $\%)$ shown in Table 3 . The results are in agreement with the conclusions of Ali et al. [19] who observed an increase in titratable acidity during preservation of persimmon slice. Similar results were investigated by Kumar et al. [20] in osmotically vacuumed dried mango slice. The increase in acidity might be due to development of acidic substances by the degradation of pectic bodies or breakdown or oxidation of reducing sugar into acid due to high temperature.

Ascorbic acid (mg/100 g): Ascorbic acid content decreased with the storage time. The mean values of ascorbic acid content were significantly decreased from 54.82 to $30.08 \mathrm{mg} / 100 \mathrm{~g}$ during storage. Maximum percent decrease was found in $\mathrm{S}_{0}(65.74 \%)$ followed by $\mathrm{S}_{6}(49.10 \%)$, while minimum percent decrease was found in $\mathrm{S}_{5}(32.93 \%)$ followed by $\mathrm{S}_{1}(37.28 \%)$ shown in Table 4 . These outcomes are in agreement with the conclusions of Kumar et al. who observed decreased in ascorbic acid content of osmo-vac dehydrated mango slices.

Reducing sugar: During storage interval amount of reducing sugars (Reducing sugars may be maintained under proper conditions quite stable at high temperature) gradually increased from 8.35 to 11.16. Maximum percent increase was found in $\mathrm{S}_{2}(43.85 \%)$ followed by $\mathrm{S}_{3}(32.18 \%)$ while minimum percent increase was found in $\mathrm{S}_{1}(24.15 \%)$ followed by $S_{5}(26.31 \%)$ while control samples i. e. $S_{0}$ showed decrease during storage as shown in Table 5. Results showed that reducing sugar increased with time but the control decreased with time. These results are shown by Wisal et al. [21] during storage of strawberry juice with different chemical preservatives and sucrose content. Kumar et al. [22] also show similar results during pineapple slices osmo dehydration.

Non reducing sugar: The mean values of non-reducing sugar of strawberry fruit samples ( $S_{0}$ to $S_{6}$ ) were decreased from 20.41 to 13.36 during storage duration. Highest percent reduction in non-reducing was occurred in $\mathrm{S}_{0}(91.40 \%)$ followed by $\mathrm{S}_{6}(38.02 \%)$, while percent lowest reduction was recorded in $\mathrm{S}_{5}(16.95 \%)$ followed by $\mathrm{S}_{1}(21.43 \%)$ as shown in Table 6. Zia and Ayub [23] observed similar results in decreased in non-reducing sugar of sucrose and glucose preserved melon cubes. Wisal et al. reviewed similar results in strawberry juice preservation in different chemical and sucrose contents.

\section{Sensory evaluation}

Color: The initial average scoring rate of the Judges for color of strawberry fruits samples were 9.0, 9.0, 9.0, 9.0, 9.0, 9.0 and 9.0 which gradually decreased to $1.00,6.10,5.40,5.70,4.70,6.50$ and 5.30 respectively for total storage duration. The average mean values for strawberry fruits preserved were considerably $(\mathrm{P}<0.05)$ declined from 9.00 to 4.96 during storage period. The maximum mean value of strawberry preserve for color was S5 (7.60) followed by S1 (7.47) while minimum mean value for color was S0 (4.13) followed by S4 (6.39). Highest percent decreased in color occurred in S0 (88.89\%) followed by $\mathrm{S} 4(47.78 \%)$ while percent lowest decreased in color occurred in S5 (27.78 \%) followed by S1 (32.22 \%) shown in Table 7. Moreno 
Citation: Khan A, Shamrez B, Litaf U, Zeb A, Rehman Z, et al. (2014) Effect of Sucrose Solution and Chemical Preservatives on Overall Quality of Strawberry Fruit. J Food Process Technol 6: 413. doi:10.4172/2157-7110.1000413

Page 3 of 6

\begin{tabular}{|c|c|c|c|c|c|c|c|c|c|}
\hline \multirow{2}{*}{ Treatments } & \multicolumn{7}{|c|}{ Storage Intervals (Days) } & \multirow{2}{*}{$\%$ Decrease } & \multirow{2}{*}{ Means } \\
\hline & 0 & 15 & 30 & 45 & 60 & 75 & 90 & & \\
\hline $\mathrm{S}_{0}$ & 3.47 & 3.44 & 3.41 & 3.40 & 3.37 & 3.34 & 3.32 & 4.32 & $3.39 d$ \\
\hline $\mathrm{S}_{1}$ & 3.51 & 3.50 & 3.48 & 3.45 & 3.42 & 3.40 & 3.37 & 3.99 & $3.45 a$ \\
\hline $\mathrm{S}_{2}$ & 3.46 & 3.44 & 3.41 & 3.38 & 3.34 & 3.31 & 3.28 & 5.20 & $3.37 e$ \\
\hline $\mathrm{S}_{3}$ & 3.49 & 3.47 & 3.45 & 3.42 & 3.39 & 3.36 & 3.31 & 5.16 & $3.41 b c$ \\
\hline $\mathrm{S}_{4}$ & 3.53 & 3.51 & 3.48 & 3.44 & 3.41 & 3.38 & 3.35 & 5.10 & $3.44 a$ \\
\hline $\mathrm{S}_{5}$ & 3.48 & 3.49 & 3.46 & 3.42 & 3.39 & 3.37 & 3.34 & 4.02 & $3.42 b$ \\
\hline $\mathrm{S}_{6}$ & 3.50 & 3.48 & 3.45 & 3.41 & 3.37 & 3.33 & 3.30 & 5.71 & $3.41 \mathrm{c}$ \\
\hline Means & $3.49 a$ & $3.48 b$ & $3.45 \mathrm{c}$ & $3.42 d$ & $3.38 \mathrm{e}$ & $3.36 f$ & $3.32 \mathrm{~g}$ & & \\
\hline
\end{tabular}

S-Soluble

Table 1: $\mathrm{pH}$ analysis of different treatments of strawberry fruit stored at ambient temperature

\begin{tabular}{|c|c|c|c|c|c|c|c|c|c|}
\hline \multirow{2}{*}{ Treatment } & \multicolumn{7}{|c|}{ Storage Intervals (Days) } & \multirow{2}{*}{$\%$ increase } & \multirow{2}{*}{ Means } \\
\hline & 0 & 15 & 30 & 45 & 60 & 75 & 90 & & \\
\hline So & 5.90 & 4.10 & 3.80 & 2.70 & 1.50 & 1.00 & 1.00 & 83.05 & $2.86 \mathrm{c}$ \\
\hline S1 & 17.00 & 18.20 & 20.00 & 20.80 & 21.40 & 21.90 & 22.60 & 24.78 & $20.27 b$ \\
\hline S2 & 21.00 & 22.60 & 23.10 & 23.50 & 24.00 & 24.30 & 25.00 & 16.00 & $23.36 a$ \\
\hline S3 & 17.40 & 18.90 & 20.00 & 20.90 & 21.80 & 22.40 & 23.30 & 25.32 & $20.67 b$ \\
\hline S4 & 20.60 & 22.50 & 24.00 & 24.50 & 25.10 & 25.70 & 26.20 & 21.37 & $24.09 a$ \\
\hline S5 & 16.80 & 18.00 & 19.20 & 19.80 & 20.50 & 20.90 & 21.70 & 22.58 & $19.56 \mathrm{~b}$ \\
\hline S6 & 21.50 & 23.10 & 23.90 & 25.00 & 25.80 & 26.70 & 27.30 & 21.25 & $24.76 a$ \\
\hline Means & $17.17 d$ & $18.20 \mathrm{~cd}$ & 19.14bc & 19.60abc & $20.01 \mathrm{ab}$ & $20.41 a b$ & $21.01 a$ & & \\
\hline
\end{tabular}

S-Soluble

Table 2: Analysis of TSS ( ${ }^{\circ}$ brix) of different treatment of strawberry fruit stored at ambient temperature

\begin{tabular}{|c|c|c|c|c|c|c|c|c|c|}
\hline \multirow{2}{*}{ Treatments } & \multicolumn{7}{|c|}{ Storage Intervals (Days) } & \multirow{2}{*}{$\%$ increase } & \multirow{2}{*}{ Means } \\
\hline & 0 & 15 & 30 & 45 & 60 & 75 & 90 & & \\
\hline $\mathrm{S}_{0}$ & 0.34 & 0.36 & 0.39 & 0.40 & 0.44 & 0.47 & 0.49 & 31.63 & $0.41 \mathrm{e}$ \\
\hline $\mathrm{S}_{1}$ & 0.39 & 0.40 & 0.43 & 0.45 & 0.46 & 0.48 & 0.52 & 25.00 & $0.45 c$ \\
\hline $\mathrm{S}_{2}$ & 0.38 & 0.41 & 0.42 & 0.47 & 0.49 & 0.50 & 0.54 & 29.63 & $0.46 \mathrm{bc}$ \\
\hline $\mathrm{S}_{3}$ & 0.41 & 0.44 & 0.47 & 0.50 & 0.54 & 0.56 & 0.59 & 30.51 & $0.50 a$ \\
\hline $\mathrm{S}_{4}$ & 0.36 & 0.37 & 0.40 & 0.42 & 0.46 & 0.48 & 0.51 & 29.41 & $0.43 d$ \\
\hline $\mathrm{S}_{5}$ & 0.40 & 0.41 & 0.43 & 0.45 & 0.48 & 0.51 & 0.55 & 27.27 & $0.46 \mathrm{~b}$ \\
\hline $\mathrm{S}_{6}$ & 0.37 & 0.39 & 0.43 & 0.40 & 0.42 & 0.46 & 0.53 & 30.19 & $0.43 d$ \\
\hline Means & $0.38 \mathrm{~g}$ & $0.40 f$ & $0.42 \mathrm{e}$ & $0.44 d$ & $0.47 c$ & $0.49 b$ & $0.53 a$ & & \\
\hline
\end{tabular}

S-Soluble

Table 3: Analysis of Titratable acidity of different treatment of strawberry fruit treatment stored at ambient tempereture

\begin{tabular}{|c|c|c|c|c|c|c|c|c|c|}
\hline \multirow{2}{*}{ Treatments } & \multicolumn{7}{|c|}{ Storage Intervals (Days) } & \multirow{2}{*}{$\%$ Decrease } & \multirow{2}{*}{ Means } \\
\hline & 0 & 15 & 30 & 45 & 60 & 75 & 90 & & \\
\hline $\mathrm{S}_{0}$ & 53.10 & 48.01 & 41.43 & 36.00 & 30.19 & 25.78 & 18.19 & 65.74 & $36.10 d$ \\
\hline $\mathrm{S}_{1}$ & 55.80 & 52.00 & 48.20 & 46.00 & 41.80 & 39.10 & 35.00 & 37.28 & $45.41 \mathrm{ab}$ \\
\hline $\mathrm{S}_{2}$ & 51.31 & 48.76 & 43.13 & 39.89 & 36.75 & 33.10 & 30.00 & 41.53 & $40.42 c$ \\
\hline $\mathrm{S}_{3}$ & 58.00 & 55.40 & 50.00 & 42.00 & 36.30 & 32.70 & 29.90 & 48.45 & $43.47 \mathrm{~b}$ \\
\hline $\mathrm{S}_{4}$ & 59.00 & 54.12 & 49.08 & 45.10 & 40.60 & 37.00 & 34.00 & 42.37 & $45.56 \mathrm{ab}$ \\
\hline $\mathrm{S}_{5}$ & 57.40 & 53.00 & 48.40 & 44.10 & 42.70 & 40.00 & 38.50 & 32.93 & $46.30 a$ \\
\hline $\mathrm{S}_{6}$ & 49.12 & 46.40 & 42.89 & 37.45 & 32.67 & 28.98 & 25.00 & 49.10 & $37.50 \mathrm{~d}$ \\
\hline Means & $54.82 a$ & $51.10 \mathrm{~b}$ & $46.16 c$ & $41.51 \mathrm{~d}$ & $37.29 \mathrm{e}$ & $33.81 f$ & $30.08 \mathrm{~g}$ & & \\
\hline
\end{tabular}

S-Soluble

Table 4: Analysis of Ascorbic acid content $(\mathrm{mg} / 100 \mathrm{~g})$ of different treatment of strawberry fruit stored at ambient temperature

et al. [24] observed color changes during ohmic heating, vacuum impregnation and osmodehydration of strawberry fruits. Mancilla et al. [25] showed similar changes in color during osmo dehydration under hydrostatic pressure of strawberry fruits. The change in strawberry color is associated with chromatic coordinates which is affected by osmodeydration under hydrostatic pressure. Perera et al. [26] observed similar results of decrease in color due browning reaction (millard) that occurred throughout storage in pineapple juice. Kumar and Devi recorded decrease in color of pineapple slice throughout storage. Colors of mango chips were also affected by osmodehydration by Zou et al. [27].

Texture: The initial score rate of the judges for texture of the strawberry fruit samples were $9.0,9.0,9.0,9.0,9.0,9.0$ and 9.0 which gradually decreased to $1.00,6.10,5.30,5.80,5.60,6.30$ and 5.90 respectively at total storage period. The average mean values for strawberry fruits preserved were considerably $(\mathrm{P}<0.05)$ declined from 9.0 to 5.14 during storage period. The higher mean value of strawberry fruit preserved for texture was found in $S_{1}$ and $S_{5}(7.46)$ followed by $S_{6}$ 
Citation: Khan A, Shamrez B, Litaf U, Zeb A, Rehman Z, et al. (2014) Effect of Sucrose Solution and Chemical Preservatives on Overall Quality of Strawberry Fruit. J Food Process Technol 6: 413. doi:10.4172/2157-7110.1000413

Page 4 of 6

\begin{tabular}{|c|c|c|c|c|c|c|c|c|c|}
\hline \multirow{2}{*}{ Treatments } & \multicolumn{7}{|c|}{ Storage Intervals (Days) } & \multirow{2}{*}{$\%$ increase } & \multirow{2}{*}{ Means } \\
\hline & 0 & 15 & 30 & 45 & 60 & 75 & 90 & & \\
\hline $\mathrm{S}_{0}$ & 5.89 & 5.34 & 4.78 & 4.21 & 3.56 & 2.57 & 1.90 & $67.74^{*}$ & $4.04 \mathrm{c}$ \\
\hline $\mathrm{S}_{1}$ & 8.89 & 9.20 & 9.84 & 10.39 & 10.61 & 11.00 & 11.74 & 24.15 & $10.24 b$ \\
\hline $\mathrm{S}_{2}$ & 7.69 & 8.50 & 9.20 & 10.33 & 11.50 & 12.52 & 13.70 & 43.85 & $10.49 a b$ \\
\hline $\mathrm{S}_{3}$ & 8.20 & 9.00 & 9.94 & 10.51 & 11.29 & 12.00 & 12.09 & 32.18 & $10.43 a b$ \\
\hline $\mathrm{S}_{4}$ & 9.42 & 10.00 & 10.47 & 11.23 & 12.04 & 12.89 & 13.37 & 29.54 & $11.35 \mathrm{ab}$ \\
\hline $\mathrm{S}_{5}$ & 8.47 & 9.05 & 9.68 & 10.09 & 10.74 & 11.16 & 11.50 & 26.31 & 10.10b \\
\hline $\mathrm{S}_{6}$ & 9.87 & 10.20 & 10.98 & 11.51 & 12.37 & 13.04 & 13.83 & 28.63 & $11.69 a$ \\
\hline Means & $8.35 \mathrm{e}$ & 8.76de & $9.27 \mathrm{cde}$ & $9.75 \mathrm{bcd}$ & 10.30abc & $10.74 b$ & $11.16 a$ & & \\
\hline
\end{tabular}

S-Soluble

Table 5: Analysis of reducing sugar (\%) of different treatments of strawberry fruit stored at ambient temperature

\begin{tabular}{|c|c|c|c|c|c|c|c|c|c|}
\hline \multirow{2}{*}{ Treatments } & \multicolumn{7}{|c|}{ Storage Intervals (Days) } & \multirow{2}{*}{$\%$ Decrease } & \multirow{2}{*}{ Means } \\
\hline & 0 & 15 & 30 & 45 & 60 & 75 & 90 & & \\
\hline $\mathrm{S}_{0}$ & 12.67 & 10.82 & 8.40 & 6.02 & 4.50 & 2.78 & 1.09 & 91.40 & $6.61 d$ \\
\hline $\mathrm{S}_{1}$ & 21.87 & 21.09 & 20.37 & 19.48 & 19.03 & 18.56 & 17.18 & 21.43 & $19.65 a$ \\
\hline $\mathrm{S}_{2}$ & 22.31 & 20.28 & 18.90 & 16.76 & 16.00 & 15.49 & 15.20 & 31.87 & $17.85 \mathrm{c}$ \\
\hline $\mathrm{S}_{3}$ & 21.30 & 20.74 & 19.24 & 17.58 & 15.81 & 15.00 & 14.67 & 31.13 & $17.76 \mathrm{c}$ \\
\hline $\mathrm{S}_{4}$ & 20.87 & 19.87 & 18.05 & 16.79 & 15.40 & 14.90 & 13.74 & 34.16 & $17.09 \mathrm{c}$ \\
\hline $\mathrm{S}_{5}$ & 21.29 & 20.74 & 19.59 & 19.14 & 18.45 & 18.09 & 17.68 & 16.95 & $19.28 \mathrm{ab}$ \\
\hline $\mathrm{S}_{6}$ & 22.54 & 21.28 & 20.81 & 18.76 & 15.18 & 14.82 & 13.97 & 38.02 & $18.19 \mathrm{bc}$ \\
\hline Means & $20.41 a$ & $19.26 a$ & $17.91 b$ & $16.36 \mathrm{c}$ & $14.91 d$ & 14.23de & $13.36 e$ & & \\
\hline
\end{tabular}

S-Soluble

Table 6: Analysis of non reducing sugar (\%) of different treatment of strawberry fruit stored at ambient temperature

\begin{tabular}{|c|c|c|c|c|c|c|c|c|c|}
\hline \multirow{2}{*}{ Treatments } & \multicolumn{7}{|c|}{ Storage Intervals (Days) } & \multirow{2}{*}{$\%$ Decrease } & \multirow{2}{*}{ Means } \\
\hline & 0 & 15 & 30 & 45 & 60 & 75 & 90 & & \\
\hline \multicolumn{10}{|c|}{ Color Score rate } \\
\hline $\mathrm{S}_{0}$ & 9.00 & 6.30 & 5.20 & 3.90 & 2.50 & 1.00 & 1.00 & 88.89 & $4.13 c$ \\
\hline $\mathrm{S}_{1}$ & 9.00 & 8.60 & 7.80 & 7.20 & 6.90 & 6.70 & 6.10 & 32.22 & $7.47 a$ \\
\hline $\mathrm{S}_{2}$ & 9.00 & 8.40 & 7.10 & 6.50 & 6.10 & 5.80 & 5.40 & 40.00 & $6.90 \mathrm{ab}$ \\
\hline $\mathrm{S}_{3}$ & 9.00 & 8.30 & 7.50 & 6.70 & 6.50 & 5.90 & 5.70 & 36.67 & 7.09ab \\
\hline $\mathrm{S}_{4}$ & 9.00 & 7.60 & 6.40 & 6.20 & 5.70 & 5.10 & 4.70 & 47.78 & $6.39 \mathrm{~b}$ \\
\hline $\mathrm{S}_{5}$ & 9.00 & 8.40 & 7.70 & 7.50 & 7.20 & 6.90 & 6.50 & 27.78 & $7.60 \mathrm{a}$ \\
\hline $\mathrm{S}_{6}$ & 9.00 & 8.00 & 7.60 & 7.10 & 6.40 & 5.90 & 5.30 & 41.11 & 7.04ab \\
\hline Means & $9.00 a$ & $7.94 b$ & $7.04 \mathrm{c}$ & $6.44 \mathrm{~cd}$ & $5.90 \mathrm{de}$ & 5.33ef & $4.96 f$ & & \\
\hline
\end{tabular}

S-Soluble

Table 7: Sensory evaluation score for color of strawberry fruit stored at ambient temperature

(7.39) while lower mean value was observed in $S_{0}$ (4.27) followed by $\mathrm{S}_{2}(6.53)$. Highest percent decreased in texture occurred in $\mathrm{S}_{0}(88.89 \%)$ followed by $\mathrm{S}_{2}(41.11 \%)$ while percent lowest decreased in texture occurred in $\mathrm{S}_{5}(30.00 \%)$ followed by $\mathrm{S}_{1}(32.22 \%)$ shown in Table 8 . These results are similar to Iman et al. [28] who conserved apple slices in sucrose/glucose solution. Maldonado et al. [29] showed decline of the texture during rehydration of mangoes. Texture is usually related to the firmness of the fruit. Aday and Caner observed changes in firmness of the strawberry fruit using an oxygen absorber in a biobased package. Change in texture might be due to cell rupture or conversion of starch to sugar. Deng and Zhao [30] observed decrease in firmness of osmodehydrated apple with storage period.

Flavor: The initial average score rate of the judges for flavor of the strawberry fruit samples were 9.0, 9.0, 9.0, 9.0, 9.0, 9.0 and 9.0 which gradually decreased to $1.00,6.50,5.60,6.20,5.70,6.70$ and 4.90 respectively during storage period. The mean value of the strawberry fruit preserved for flavor considerably $(\mathrm{P}<0.05)$ declined from 9.0 to 5.23 at total storage period. The higher mean value for flavor of the strawberry fruit preserved was observed in $\mathrm{S}_{3}$ and $\mathrm{S}_{5}(7.60)$ followed by $S_{1}$ (7.51) while lower mean value was observed in $S_{0}(4.50)$ followed by
$\mathrm{S}_{6}(6.61)$. Highest percent decreased in flavor score was observed in $\mathrm{S}_{0}$ (88.89\%) followed by $\mathrm{S}_{6}(45.56 \%)$ while percent lowest decreased was observed in $\mathrm{S}_{5}(25.56 \%)$ followed by $\mathrm{S}_{1}(27.78 \%)$ shown in Table 9.

Similar results were also observed by Torres et al. [31] loss of aromatic occurred in osmo dehydration of mango and concluded that high osmodeydration level, effect the volatile compound negatively while lower osmodehydration level give rise to enhancement of the volatile profile. Pani et al. [32] observed degradative event during osmodehydration and air dehydration of tomato slices. Habib et al. [33] also observed decline in flavor mango. Osmotic treatments stimulated alterations in the volatile profile of mango were observed for strawberry by Escriche et al. and in kiwi by Talens et al. [34].

Overall acceptability: The mean score for overall acceptability of the strawberry fruit preserve decreased from 9.00 to 5.40. Highest percent decreased in overall acceptability was founded in $\mathrm{S}_{0}(88.89 \%)$ followed by $S_{6}(46.67 \%)$, while the lowest percent decreased was occurred in $S_{1}(25.56 \%)$ followed by $S_{5}(26.67 \%)$ as shown in Table 10. These results are in commerce with Sabrina et al. [35] who observed decline in the overall acceptability of osmo dehydrated mango slices with inverted sugar syrups and sucrose [36]. 
Citation: Khan A, Shamrez B, Litaf U, Zeb A, Rehman Z, et al. (2014) Effect of Sucrose Solution and Chemical Preservatives on Overall Quality of Strawberry Fruit. J Food Process Technol 6: 413. doi:10.4172/2157-7110.1000413

Page 5 of 6

\begin{tabular}{|c|c|c|c|c|c|c|c|c|c|}
\hline \multirow{2}{*}{ Treatments } & \multicolumn{7}{|c|}{ Storage Intervals (Days) } & \multirow{2}{*}{$\%$ Decrease } & \multirow{2}{*}{ Means } \\
\hline & 0 & 15 & 30 & 45 & 60 & 75 & 90 & & \\
\hline \multicolumn{10}{|c|}{ Texture Score rate } \\
\hline $\mathrm{S}_{0}$ & 9.00 & 6.60 & 4.80 & 3.70 & 2.80 & 2.00 & 1.00 & 88.89 & $4.27 \mathrm{c}$ \\
\hline $\mathrm{S}_{1}$ & 9.00 & 8.50 & 7.90 & 7.30 & 6.90 & 6.50 & 6.10 & 32.22 & $7.46 a$ \\
\hline $\mathrm{S}_{2}$ & 9.00 & 7.50 & 6.30 & 6.10 & 5.80 & 5.70 & 5.30 & 41.11 & $6.53 b$ \\
\hline $\mathrm{S}_{3}$ & 9.00 & 8.20 & 7.80 & 7.20 & 6.80 & 6.30 & 5.80 & 35.56 & $7.30 \mathrm{a}$ \\
\hline $\mathrm{S}_{4}$ & 9.00 & 8.10 & 7.50 & 7.10 & 6.70 & 6.20 & 5.60 & 37.78 & 7.17ab \\
\hline $\mathrm{S}_{5}$ & 9.00 & 8.00 & 7.80 & 7.40 & 7.00 & 6.70 & 6.30 & 30.00 & $7.46 a$ \\
\hline $\mathrm{S}_{6}$ & 9.00 & 8.30 & 7.90 & 7.40 & 6.80 & 6.40 & 5.90 & 34.44 & $7.39 a$ \\
\hline Means & $9.00 \mathrm{a}$ & $7.89 b$ & $7.14 \mathrm{c}$ & $6.60 \mathrm{~cd}$ & 6.11de & 5.69ef & $5.14 f$ & & \\
\hline
\end{tabular}

S-Soluble

Table 8: Sensory evaluation score for texture of strawberry fruit stored at ambient temperature

\begin{tabular}{|c|c|c|c|c|c|c|c|c|c|}
\hline \multirow{2}{*}{ Treatments } & \multicolumn{7}{|c|}{ Storage Intervals (Days) } & \multirow{2}{*}{$\%$ Decrease } & \multirow{2}{*}{ Means } \\
\hline & 0 & 15 & 30 & 45 & 60 & 75 & 90 & & \\
\hline \multicolumn{10}{|c|}{ Flavor Score rate } \\
\hline $\mathrm{S}_{0}$ & 9.00 & 6.00 & 5.30 & 4.50 & 3.40 & 2.30 & 1.00 & 88.89 & $4.50 \mathrm{c}$ \\
\hline $\mathrm{S}_{1}$ & 9.00 & 8.30 & 7.70 & 7.40 & 7.00 & 6.70 & 6.50 & 27.78 & $7.51 \mathrm{a}$ \\
\hline $\mathrm{S}_{2}$ & 9.00 & 8.20 & 7.60 & 7.20 & 6.90 & 6.30 & 5.60 & 37.78 & $7.26 a b$ \\
\hline $\mathrm{S}_{3}$ & 9.00 & 8.30 & 8.10 & 7.60 & 7.10 & 6.90 & 6.20 & 31.11 & $7.60 a$ \\
\hline $\mathrm{S}_{4}$ & 9.00 & 8.00 & 7.70 & 7.30 & 6.70 & 6.20 & 5.70 & 36.67 & 7.23ab \\
\hline $\mathrm{S}_{5}$ & 9.00 & 8.10 & 7.90 & 7.50 & 7.10 & 6.90 & 6.70 & 25.56 & $7.60 \mathrm{a}$ \\
\hline $\mathrm{S}_{6}$ & 9.00 & 7.70 & 7.10 & 6.40 & 5.90 & 5.30 & 4.90 & 45.56 & $6.61 \mathrm{~b}$ \\
\hline Means & $9.00 \mathrm{a}$ & $7.80 \mathrm{~b}$ & $7.34 \mathrm{bc}$ & $6.84 \mathrm{~cd}$ & $6.30 \mathrm{de}$ & $5.80 \mathrm{ef}$ & $5.23 f$ & & \\
\hline
\end{tabular}

S-Soluble

Table 9: Sensory evaluation score for flavor of strawberry fruit stored at ambient temperature

\begin{tabular}{|c|c|c|c|c|c|c|c|c|c|}
\hline \multirow{2}{*}{ Treatments } & \multicolumn{7}{|c|}{ Storage Intervals (Days) } & \multirow{2}{*}{$\%$ Decrease } & \multirow{2}{*}{ Means } \\
\hline & 0 & 15 & 30 & 45 & 60 & 75 & 90 & & \\
\hline \multicolumn{10}{|c|}{ Score Rate } \\
\hline $\mathrm{S}_{0}$ & 9.00 & 7.60 & 5.30 & 3.80 & 1.70 & 1.00 & 1.00 & 88.89 & $4.20 c$ \\
\hline $\mathrm{S}_{1}$ & 9.00 & 8.30 & 8.00 & 7.70 & 7.50 & 7.20 & 6.70 & 25.56 & $7.77 \mathrm{a}$ \\
\hline $\mathrm{S}_{2}$ & 9.00 & 8.40 & 8.20 & 8.00 & 7.60 & 7.10 & 6.50 & 27.78 & $7.83 a$ \\
\hline $\mathrm{S}_{3}$ & 9.00 & 8.20 & 7.80 & 7.60 & 7.10 & 6.70 & 6.20 & 31.11 & $7.51 \mathrm{a}$ \\
\hline $\mathrm{S}_{4}$ & 9.00 & 8.10 & 7.60 & 7.20 & 6.80 & 6.30 & 6.00 & 33.33 & $7.29 a b$ \\
\hline $\mathrm{S}_{5}$ & 9.00 & 8.40 & 8.10 & 7.80 & 7.40 & 7.00 & 6.60 & 26.67 & 7.76a \\
\hline $\mathrm{S}_{6}$ & 9.00 & 7.70 & 6.50 & 5.90 & 5.30 & 4.90 & 4.80 & 46.67 & $6.30 \mathrm{~b}$ \\
\hline Means & $9.00 a$ & 8.10ab & $7.36 \mathrm{bc}$ & $6.86 \mathrm{~cd}$ & $6.20 \mathrm{de}$ & $5.74 \mathrm{e}$ & $5.40 e$ & & \\
\hline
\end{tabular}

S-Soluble

Table 10: Sensory evaluation of overall acceptability score of strawberry fruit stored at ambient temperature

\section{Conclusions and Recommendations}

In this research study strawberry fruits were preserved using different concentration of sucrose solutions and chemical preservatives, stored in plastic jars at ambient temperature It is concluded from the present research study that treatments $S_{5}$ (Strawberry fruit + sucrose solution $\left(30^{\circ}\right.$ brix $)+$ Sodium benzoate $0.05 \%+$ Potassium sorbate $0.05 \%)$ followed by $S_{1}$ (Strawberry fruit + sucrose solution $\left(30^{\circ}\right.$ brix) + Sodium benzoate $0.1 \%$ ) were found superior during physiochemical and organoleptic evaluation.

The evaluation of strawberry's quality during storage in sugar solutions at 30 and $40{ }^{\circ}$ brix with two different preservative agents at 2 different concentrations at room temperature (alone and combined). The physicochemical and organoleptical quality criteria are relevant.

Recommendation for further research work on this study:

1. The same study should be carried out in glass jars and in color jars.

2. Such study should be carried out at freezing and refrigeration temperature.
3. Further research work should be done at other sucrose concentration or other sweeteners.

\section{Acknowledgement}

Special thanks to Pro. Dr. Alam Zeb and Mr. Falak Naz Shah for their kind and keen support through our research work

\section{References}

1. Childer NF (1983) Strawberry growing. Modern Fruit Science, Gainesvile. Hort Publ.

2. John (1994) Fruit size and general characteristics of strawberry varieties InfosParis 117: 19-23.

3. Amin (1996) Progress and prospects of strawberry production in NWFP. Annual Report, Agricultural Research Station (North) Mingora, Swat 212: 4-7.

4. Aslam M, Rasool S (2012) Potential of strawberry's export from Pakistan.

5. Food and Agriculture Organization (FAO) (2009) Data on Potassium sorbate in food and beverages. United States Food and Drug Administration.

6. U.S. Dept. of Agriculture USDA (2011) Nutrient database for standard reference. Oregon. Strawberries.org. 
Citation: Khan A, Shamrez B, Litaf U, Zeb A, Rehman Z, et al. (2014) Effect of Sucrose Solution and Chemical Preservatives on Overall Quality of Strawberry Fruit. J Food Process Technol 6: 413. doi:10.4172/2157-7110.1000413

7. USDA (1998) Nutrient database for standard reference. U. S. Deptt. Agric.

8. Hakkinen SH, Torronen AR (2000) Content of flavonols and selected phenolic acids in strawberries and Vaccinium species, influence of cultivar, cultivation site and technique. Food Res Int 33: 517-524.

9. Johnson AH, Peterson MS (1974) Encyclopedia of Food Technology. The AVI Co. Inc. Westport. Connenticut, USA.

10. Galleta, Bringhurst (1995) Small fruit culture and nutritional value. The AV publishing west report. USA.

11. Sapata ML, Ferreira A, Andrada L, Leitão AE, Candeias M (2009) Osmotic dehydration of mandarins: Influence of reutilized osmotic agent on behavior and product quality. Acta Sci Pol Tech Aliment 8: 23-35.

12. Aday MS, Caner C (2013) The shelf life extension of fresh strawberries using an oxygen absorber in the biobased package. L. W. T. Food Tech 52: 102-109.

13. Krebs HA, Wiggins D, Stubbs M, Sols A, Bedoya F (1983) Studies on the mechanism of the antifungal action of benzoate. Biochem J 214: 657-663.

14. AOAC (2012) Official Methods of Analysis of AOAC International, 19th edition, volume II. Association of Official Analytical Chemists. Gaithersburg, Maryland 20877-2417, USA.

15. Larmond E (1977) Laboratory methods of sensory evaluation of foods Publication 1673. Canada. Deppt. Agri. Ottawa.

16. Steel RGD, Torrie JH (1997) Principles and procedures of statistics. A Biometrical approach, 3rd Ed., McGraw Hill book Co. NY. USA

17. Fasogbon BM, Gbadamosi SO, Taiwo KA (2013) Studies on the Osmotic Dehydration and Rehydration Characteristics of Pineapple Slices. J Food Proc Tech 4: 220-228.

18. Khan MM (2010) Preservation of strawberry syrup with benzoate and sorbate M.Sc. Theis. Dept. of Food Sci. \& Tech. Agri. Uni. Peshawar.

19. Ali A, Abrar M, Sultan MT, Din A, Niaz B (1999) Postharvest physicochemical changes in full ripe strawberries during cold storage. Ani PI Sci 21: 38-41.

20. Kumar SP, Sagarand VR (2008) Quality of osmovac dehydrated ripe mango slices influenced by packaging material and storage temperature. J Sci Industrial Res 67: 1108-1114.

21. Wisal S, Ullah J, Zeb A, Khan MZ (2013) Effect of refrigeration temperature sugar concentrations and different chemicals preservatives on the storage stability of strawberry juice. Int J Engg Tech 13: 160-168.

22. Kumar SP, Devi P (2011) Optimization of some process variable in mass transfer kinetics of osmotic dehydration of pineapple slices. Int. Food Res $\mathrm{J}$ 18: $221-238$
23. Zia A, Ayub M (2012) Quality evaluation of melon cubes preserved in sweetener solution. M.Sc. Thesis. Food Sci. Tech. Deptt. Uni. Agri. Peshawar.

24. Escriche I, Chiralt A, Moreno J, Serra JA (2000) Influence of blanching-osmotic dehydration treatments on volatile fraction of strawberry. J Food Sci 65: 1107-1111.

25. Mancilla YN, Won MP, Uribe E, Galvez AV, Scala KD (2013) Osmotic dehydration under high hydrostatic pressure: Effects on antioxidant activity, total phenolics compounds, vitamin $\mathrm{C}$ and color of strawberry (Fragariavesca) L.W.T. Food Sci Tech 52: 151-156.

26. Perera N, Gamage TV, Wakeling L, Gamlath GGS, Versteeg C (2010) Colo and texture of apple high pressure processed in pineapple juice. Innovative Food Sci. Emerging Tech 11: 39-46.

27. Zou K, Teng J, Huang L, Dai X, Wei B (2013) Effect of osmotic pretreatment on quality of mango chips by explosion puffing drying. L.W.T. Food Sci Tech 51: 253-259.

28. Iman S, Ayub M, Abbas M, Qazi IM (2006) Analysis of intermediate moisture apple slices during storage. Sarhad J Agric 22: 545-549.

29. Maldonado S, Arnau E, Bertuzzi MA (2010) Effect of temperature and pretreatment on water diffusion during rehydration of dehydrated mangoes. J Food Eng 96: 333-341.

30. Deng $Y$, Zhao $Y$ (2008) Effects of pulsedvacuum and ultrasound on the osmodehydration kinetics and microstructure of apples (Fuji). J Food Eng 85: 84-93.

31. Torres JD, Talens $P$, Carot JM, Chiralt A, Escriche I (2007) Volatile profile of mango (Mangiferaindica L.), as affected by osmotic dehydration. Food Chem. 101: 219-228.

32. Pani $P$, Leva AA, Riva M, Maestrelli A and Torreggiani D (2008) Influence of an osmotic pretreatment on structure property relationships of air dehydrated tomato slices. J Food Eng 86: 105-112.

33. Habib AR, Masud T, Sammi S, Soomro AH (2007) Effect of storage on physiochemical composition and sensory properties of mango (mangiferaincdica L.) variety Dosehri. Pak J Nut 6: 143-148.

34. Talens P, Escriche I, Navarrete NM, Chiralt A (2003) Influence of osmotic dehydration and freezing on the volatile profile of kiwi fruit. Food Res Int 36 635-642.

35. Sabrina B, Renata BB, Bruna M, Petrus RR, Carmen, et al. (2009) Quality and sensorial characteristics of osmotically dehydrated mango with syrups of inverted sugar and sucrose. Sci. Agric. (Piracicaba, Braz) 66: 40-43

36. Ayub M, Zeb A, Ullah J, Khattak MMAK (2005) Effect of nonnutritive sweeteners, chemical preservatives and antioxidants on microbial and sensory characteristics of dehydrated guava. J Sc Tech Uni Peshawar. 